OPEN ACCESS

Edited by:

Jérôme Paggetti, Luxembourg Institute of Health,

Luxembourg

Reviewed by:

Jorge Castillo,

Dana-Farber Cancer Institute,

United States

Michael Mian,

Ospedale di Bolzano, Italy

*Correspondence:

Giovanni D'Arena

giovannidarena@libero.it

Specialty section:

This article was submitted to

Hematologic Malignancies,

a section of the journal

Frontiers in Oncology

Received: 17 July 2020 Accepted: 27 October 2020 Published: 26 November 2020

Citation:

D'Arena G, De Feo V, Pietrantuono G, Seneca $E$, Mansueto $G$, Villani $O$,

La Rocca F, D'Auria F, Statuto T, Valvano L, Arruga F, Deaglio $S$, Efremov DG, Sgambato A and Laurenti L (2020) CD200 and Chronic Lymphocytic Leukemia: Biological and Clinical Relevance.

Front. Oncol. 10:584427. doi: 10.3389/fonc. 2020.584427

\section{CD200 and Chronic Lymphocytic Leukemia: Biological and Clinical Relevance}

\author{
Giovanni D'Arena ${ }^{1 *}$, Vincenzo De Feo ${ }^{2}$, Giuseppe Pietrantuono ${ }^{3}$, Elisa Seneca ${ }^{3}$, \\ Giovanna Mansueto ${ }^{3}$, Oreste Villani ${ }^{3}$, Francesco La Rocca ${ }^{4}$, Fiorella D'Auria ${ }^{5}$, \\ Teodora Statuto ${ }^{5}$, Luciana Valvano ${ }^{5}$, Francesca Arruga ${ }^{6}$, Silvia Deaglio ${ }^{6}$, \\ Dimitar G. Efremov ${ }^{7}$, Alessandro Sgambato ${ }^{8}$ and Luca Laurenti ${ }^{9}$
}

1 Hematology, "S. Luca" Hospital, ASL Salerno, Vallo della Lucania, Italy, ${ }^{2}$ Department of Pharmaceutical and Biomedical Sciences, University of Salerno, Salerno, Italy, ${ }^{3}$ Hematology and Stem Cell Transplantation Unit, IRCCS Centro di Riferimento Oncologico della Basilicata, Rionero in Vulture, Italy, ${ }^{4}$ Laboratory of Preclinical and Translational Diagnostics, IRCCS Centro di Riferimento Oncologico della Basilicata, Rionero in Vulture, Italy, ${ }^{5}$ Laboratory of Clinical Research and Advanced Diagnostics, IRCCS Centro di Riferimento Oncologico della Basilicata, Rionero in Vulture, Italy, ${ }^{6}$ Cancer Immunogenetics Unit, Department of Medical Sciences, Molecular Biotechnology Center, University of Turin, Turin, Italy, ${ }^{7}$ Molecular Hematology, International Centre for Genetic Engineering and Biotechnology, Trieste, Italy, ${ }^{8}$ Scientific Direction, IRCCS Centro di Riferimento Oncologico della Basilicata, Rionero in Vulture, Italy, ${ }^{9}$ Hematology Institute, IRCCS Fondazione Policlinico Universitario A. Gemelli, Rome, Italy

CD200, a transmembrane type la glycoprotein belonging to the immunoglobulin protein superfamily, is broadly expressed on a wide variety of cell types, such as B lymphocytes, a subset of $\mathrm{T}$ lymphocytes, dendritic cells, endothelial and neuronal cells. It delivers immunosuppressive signals through its receptor CD200R, which is expressed on monocytes/myeloid cells and T lymphocytes. Moreover, interaction of CD200 with CD200R has also been reported to play a role in the regulation of tumor immunity. Overexpression of CD200 has been reported in chronic lymphocytic leukemia (CLL) and hairy cell leukemia but not in mantle cell lymphoma, thus helping to better discriminate between these different $\mathrm{B}$ cell malignancies with different prognosis. In this review, we focus on the role of CD200 expression in the differential diagnosis of mature B-cell neoplasms and on the prognostic significance of CD200 expression in CLL, where conflicting results have been published so far. Of interest, increasing evidences indicate that anti-CD200 treatment might be therapeutically beneficial for treating CD200-expressing malignancies, such as CLL.

Keywords: CD200, chronic lymphocytic leukemia, prognosis, diagnosis, flow cytometry

\section{INTRODUCTION}

Mature B-cell leukemias are heterogeneous in clinical and biological features. Despite the large body of studies published, difficulties to get a firm diagnosis still exist in some cases due to the lack of disease-specific markers and overlapping immunophenotypes. CD200 has recently emerged as a useful tool to better discriminate among several chronic leukemias. In addition to the usefulness of this marker in the diagnostic setting, it also has a prognostic role and may represent a potential therapeutic target in chronic lymphocytic leukemia (CLL). 
In this review, we provide a summary of published data on the biological and clinical relevance of CD200 in CLL, identified through a literature search of the MEDLINE, Google Scholar, and Scopus databases, aiming at providing an update of the published literature on this topic. The search comprised the terms "CD200", "chronic lymphocytic leukemia", and "chronic B cell leukemias" without a date restriction. All articles and Meeting Abstracts we found were evaluated and included in this review.

\section{CD200 ANTIGEN AND CD200 RECEPTOR}

The surface membrane glycoprotein CD200, formerly termed OX-2, is encoded by the 29,744 bp long CD200 (OX-2) gene located on the long arm of chromosome 3 (3q13.2) (1). Three transcript variants of CD200 are known: variant 1, 2,226 bp long, containing 7 exons and encoding the 269 amino acids long isoform a; variant 2, 2,301 bp long, containing 7 exons and encoding the 294 amino acids long isoform b; and variant 3, $2,085 \mathrm{bp}$ long, missing an exon and encoding the 153 amino acids long isoform c (2).

The CD200 glycoprotein is a single-pass, type I, highly conserved membrane protein, belonging to the immunoglobulin superfamily, spanning the membrane once, with the N-terminus on the extracellular side of the membrane (2). It is composed of two extracellular (one variable and one constant) immunoglobulin-like domains, a single transmembrane region, and a cytoplasmic tail (Figure 1) (3).

The receptor for CD200 (CD200R) also has two immunoglobulin-like domain. The phylogenetic analysis

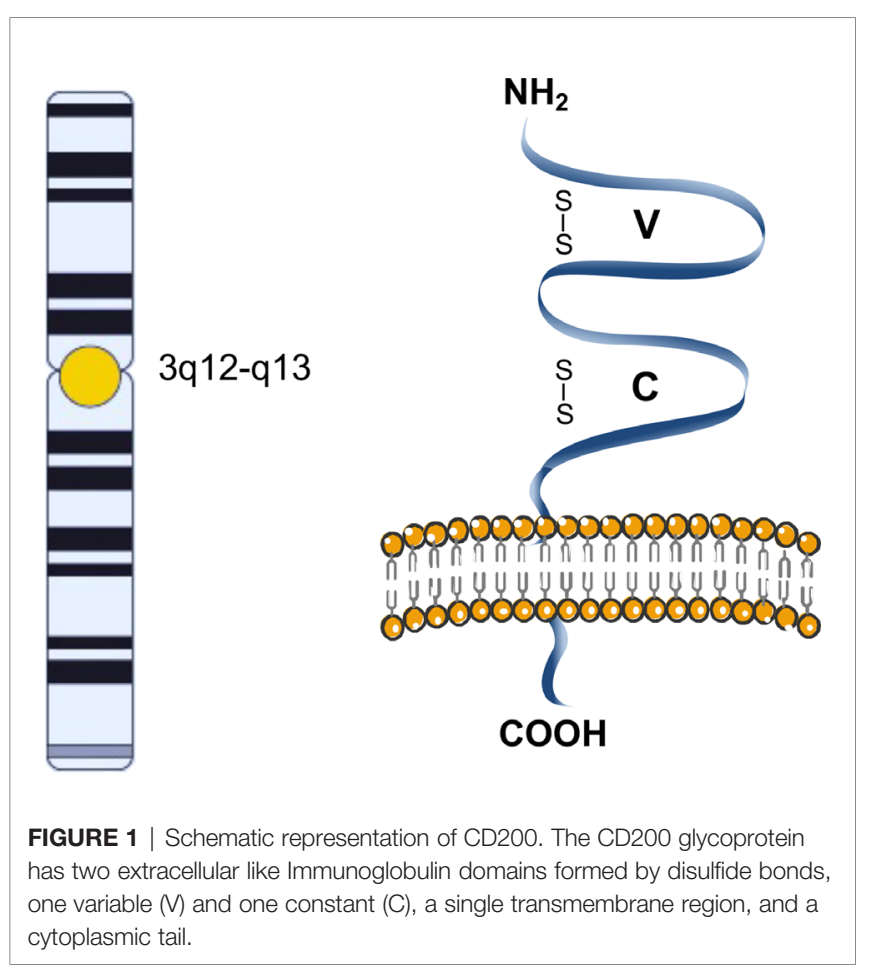

demonstrated that the receptor is closely related to CD200 and probably evolved by a gene duplication (2). As a matter of the fact, the genes for human CD200 and CD200R are closely linked on chromosome 3 (4). However, the CD200R has a longer cytoplasmic tail with signaling motifs different from CD200 (5).

CD200 is normally expressed on a variety of cell types, including thymocytes, B lymphocytes, a subset of $\mathrm{T}$ lymphocytes, neurons, endothelial cells, some dendritic cells, kidney glomeruli, and syncytiothrophoblasts (6). The expression of CD200R is more restricted and includes myeloid leucocytes, such as macrophages, dendritic cells, and mast-cells, as well as B lymphocytes and a subset of T lymphocytes $(7,8)$.

\section{FUNCTION OF CD200 AND ITS ROLE IN CANCER}

CD200, by means of the interaction with its receptor, induces the suppression of T-cell mediated responses, limiting inflammation in a wide range of inflammatory diseases (Table 1). The inhibition of macrophage function, induction of regulatory $\mathrm{T}$ helper cell type (Th1) to Th2 cytokine profile switch, suppression of natural killer cell function, and inhibition of tumor-specific Tcell immunity have been all experimentally demonstrated (9-14, 15-18). Consistent with its immunosuppressive role, CD200deficient mice are susceptible to tissue-specific autoimmunity (15). Gorczynski and co-workers demonstrated that the interaction of CD200 with CD200R is able to decrease the production of Th1-like cytokines, such as interleukin (IL)-2 and interferon (IF)- $\gamma$, and increase the release of Th2-like cytokines, such as IL-10 and IL-4 (16). In addition, the same group reported that the CD200/CD200R interaction induces the in vitro differentiation of $\mathrm{T}$ lymphocytes toward $\mathrm{CD} 4^{+} \mathrm{CD} 25^{+} \mathrm{Foxp}^{+}$ regulatory T-cells (Tregs) (16).

Moreaux et al demonstrated that CD200 mRNA is overexpressed on cells of several types of cancers compared to their normal counterparts, including chronic lymphocytic leukemia (CLL) (19). Kretz-Rommel et al elaborated a tumor model on the basis of the previous demonstration that CD200 is up-regulated in CLL and that the up-regulation in multiple myeloma (MM) and acute myeloid leukemia (AML) correlates with adverse prognosis (20-22). These authors firstly demonstrated that human peripheral blood mononuclear cells (hPBMCs) and Namalwa tumor cells (Burkitt's lymphoma cell line lacking CD200 expression) simultaneously injected in

TABLE 1 | CD200:CD200R interaction and negative control of immunity.

\section{KEY FACTS}

Reduced Th1 cytokine (IL-2, IFN $\gamma$ ) production (9)

Increased IL-10 and IL-4 production (9)

Induction of Tregs (10)

Inhibition of mast cell degranulation $(11,12)$

Downregulation of basophilic function (13)

Suppression of natural killer cell function (14)

CD200R, receptor of CD200 antigen; Th, Thelper; IL, interleukin; IFN, interferon; Tregs, regulatory $T$-cells. 
NOD/SCID mice show reduced tumor growth with respect to that observed in mice in the absence of hPBMCs $(23,24)$. When the Namalwa tumor cells were engineered to express human CD200 on their surface and simultaneously injected with hPBMCs, CD200 expressed on tumor cells prevented hPBMCs from eradicating the cancer cells. This tumor model clearly demonstrated the immunosuppressive activity of CD200. Moreover, treatment with anti-CD200 monoclonal antibodies (Abs) was also highly effective in this model and inhibited the growth of Namalwa CD200 tumor cells in NOD/SCID hu-mice by $>90 \%$. The same study showed that CD200 is a marker of activated T cells and that the use of IgG1 anti-CD200 (a constant region variant that can mediate ADCC) resulted in efficient target cell killing of these lymphocytes by ADCC. Taken together, these data have relevant implications for the immunotherapy of cancer patients with anti-CD200.

\section{RELEVANCE OF CD200 IN DIAGNOSIS OF CHRONIC LYMPHOPROLIFERATIVE DISORDERS}

The neoplasms of mature B cells are heterogeneous diseases currently included in the "mature B-cell lymphoid neoplasms" of the WHO classification $(25,26)$. Immunophenotypic profile, cytogenetics, and molecular biology must be all taken into account as a multidisciplinary integrated approach to differentiate the disease entities belonging to this category. However, difficulties in defining some cases still exist. Diagnostic accuracy is crucial in diagnosing neoplasms that require different specific treatments.

Flow cytometric characterization of chronic lymphoproliferative disorders represents a cornerstone in the diagnostic approach to neoplasms of mature lymphocytes (27). In the early 90s, a British group in London proposed a scoring system (Matutes score), which was based on analysis of 5 membrane markers: CD5, CD22, CD23, FMC7, and surface immunoglobulin (SmIg) (28). A score of 1 was assigned for each of the following immunophenotypic features: CD5 positive, CD22 weak or negative, CD23 positive, FMC7 negative, SmIg weak. The total score, according to this scoring system, is usually 4 or 5 for typical CLL cases, and 3 or less for other mature B-cell lymphoid neoplasms (28). A few years later, the same group improved the diagnostic accuracy of the score (from $91.8 \%$ to $96.8 \%$ ) simply replacing CD22 with CD79b (29).

The Matutes score is used worldwide as a diagnostic tool. However, some cases of chronic lymphoid neoplasms are still misdiagnosed, including some cases belonging to a more aggressive entity, such as mantle cell lymphoma (MCL). In this context, CD200 has been shown to have differential expression in B-cell neoplasms and to well discriminate CLL from MCL and hairy cell leukemia (HCL) and its variant form (v-HCL) (Figure 2) (30-32).

The reports on the relevance of CD200 expression to differentiate $\mathrm{B}$ cell chronic lymphoid neoplasms that have been published so far are listed in Table 2. Firstly, Palumbo et al in 2009 demonstrated that CLL can be differentiated from MCL according to the expression of CD200 (all patients with CLL expressed CD200, whereas all patients with MCL were negative) (31). At the same time Brunetti et al, analyzing only patients with HCL, showed that all patients with typical HCL expressed CD200 (30). Shortly after, Dorfman \& Shahsafaei studied by means of flow cytometry bone marrow and lymph node aspirates from patients with different mature B cell lymphoid neoplasms, showing that CLL and HCL cases were all CD200 positive, prolymphocytic leukemia (PLL) were positive in $80 \%$ of cases, while MCL, splenic marginal zone lymphoma (SMZL), and follicular lymphoma (FL) were all negative (32). Since then, several other researchers analyzed samples from patients with mature B-cell lymphoid neoplasms (33-63). Overall, the published data confirmed the positivity in all patients with
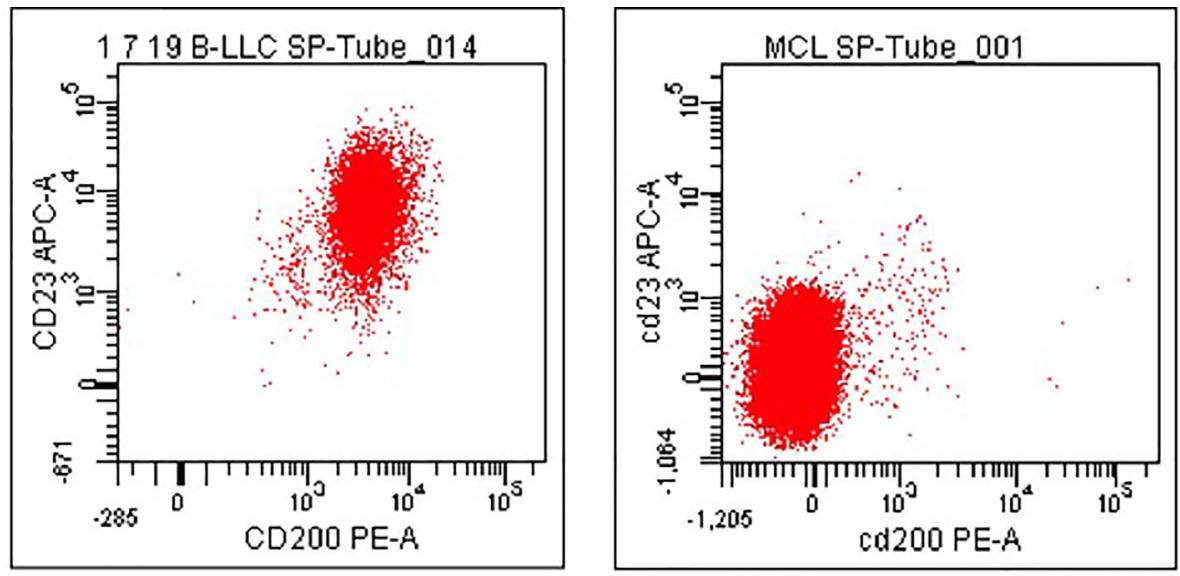

FIGURE 2 | CD200 expression in CLL and MCL. Dot plots showing a case of CLL in which both surface CD200 and CD23 were expressed (left panel) and a case of $\mathrm{MCL}$ in which both antigens were found negative (right panel). B-cells only have been gated for the analysis. 
TABLE 2 | CD200 expression and differential diagnosis in chronic B-cell leukemias: published data at a glance.

\begin{tabular}{|c|c|c|c|c|c|c|c|c|c|c|}
\hline Reference & $\begin{array}{c}\text { No. } \\
\text { Patients }\end{array}$ & Samples evaluated & CLL & MCL & $\mathrm{HCL}$ & HCL-v & MZL & FL & LPL & Other B-cell neoplasms \\
\hline Palumbo et al. (31) & 91 & PB & 79/79 (100\%) & 0/14 (0\%) & - & - & - & - & - & - \\
\hline Brunetti et al. (30) & 10 & PB; BM & - & - & $\begin{array}{c}10 / 10 \\
(100 \%)\end{array}$ & - & - & - & - & - \\
\hline $\begin{array}{l}\text { Dorfman and } \\
\text { Shahsafaei (32) }\end{array}$ & 73 & BM, LN" & $21 / 21(100 \%)$ & 0/10 (0\%) & $12 / 12(100 \%)$ & - & $0 / 10(0 \%)$ & $0 / 16(0 \%)$ & $\begin{array}{l}8 / 10 \\
(80 \%)\end{array}$ & $\begin{array}{l}\text { MALT: O/4 (0\%); B lymphoblastic leukemia } \\
\text { lymphoma: 10/10 (100\%); DLBCL: 0/12 } \\
\text { (0\%); mediastinal large B-cell lymphoma: } 8 \\
8 \text { (100\%); BL: 0/8 (0\%); MM: 10/13 (77\%); } \\
\text { HL: 12/13 (92\%); nodular lymphocyte } \\
\text { predominant HL: 0/14 (0\%) }\end{array}$ \\
\hline Bhatnagar et al. (33) & 100 & PB; BM & 78/78 (100\%) & $0 / 7(0 \%)$ & - & - & - & - & - & - \\
\hline El Desoukey et al. (34) & 49 & PB & $31 / 31(100 \%)$ & $0 / 4(0 \%)$ & $2 / 2(100 \%)$ & - & $0 / 4(0 \%)$ & 0/8 (0\%) & - & - \\
\hline Cherian et al. (35) & 66 & Not reported & - & - & - & - & - & - & - & $\begin{array}{l}\text { Not reported data as percentage } \\
\text { expression of CD200 in } 51 \text { cases of CLL } \\
\text { SLL and } 15 \text { cases of MCL. Most cases } \\
\text { studied can be separated using a cut off of } \\
1.10 \text { for the CD200 MFI ratio }\end{array}$ \\
\hline Kern et al. (36) & 100 & PB, BM & $\begin{array}{l}58 / 59 \\
(98,3 \%)\end{array}$ & $2 / 14(14,3 \%)$ & - & - & - & - & - & CLL/PL cases: 26/27 (96.3\%) \\
\hline Alapat et al. (37) & 107 & $\begin{array}{l}\text { PB; BM; LN; body } \\
\text { fluids }\end{array}$ & 19/19 (100\%) & $0 / 4(0 \%)$ & - & - & - & - & $\begin{array}{c}3 / 7 \\
(43 \%)\end{array}$ & $\begin{array}{l}\text { B-ALL: 19/20 (95\%); T-ALL: 0/5 (0\%); MM } \\
37 / 52 \text { (71\%) }\end{array}$ \\
\hline Pillai et al. (38) & 180 & $\begin{array}{l}\text { BM, PB, LN; body } \\
\text { fluids and other } \\
\text { tissues }\end{array}$ & - & - & 23/23 (100\%) & $1 / 1 \mathrm{O}(10 \%)$ & - & - & - & $\begin{array}{l}\text { Not specified the number of positive/ } \\
\text { negative cases but only reported MFI (with } \\
\text { range) for each disease category. CLL/SLL } \\
\text { showed CD200 with MFI of 5,965 } \\
\text { compared with MCL and FL which had } \\
\text { MFIs of } 397 \text { and 521, respectively. }\end{array}$ \\
\hline Dasgupta et al. (39) & 56 & Not reported & 28/28 (100\%) & $\begin{array}{l}2 / 10 \\
(20 \%)\end{array}$ & $3 / 3(100 \%)$ & - & - & - & - & 4/8 (50\%) not otherwise specified \\
\hline El-Sewefy et al. (40) & 40 & Not reported & $30 / 30(100 \%)$ & $1 / 10(10 \%)$ & - & - & - & - & - & \\
\hline Sandes et al. (41) & 159 & PB; BM; LN; CSF & $\begin{array}{c}56 / 56 \\
(100 \%)^{\star \star}\end{array}$ & $\begin{array}{l}0 / 14 \\
(0 \%)\end{array}$ & $\begin{array}{c}13 / 13 \\
(100 \%)\end{array}$ & - & $\begin{array}{c}6 / 6 \\
(100 \%)\end{array}$ & $\begin{array}{l}8 / 11 \\
(73 \%)\end{array}$ & $\begin{array}{c}2 / 4 \\
(50 \%)\end{array}$ & $\begin{array}{l}\text { PL: } 2 / 7(28 \%) \\
\text { SRPBL: } 1 / 1 \text { (100\%) } \\
\text { CD5-CD10- unclassifiable NHL: 21/31 } \\
(68 \%) \\
\text { CD5+ NHL } \\
\text { 9/23 (39\%) }\end{array}$ \\
\hline Challagundla et al. (42) & 364 & PB; BM; FNA; LN & $119 / 119$ (100\%) & $\begin{array}{l}58 / 61 \\
(95 \%)^{*}\end{array}$ & $\begin{array}{c}7 / 7 \\
(100 \%)\end{array}$ & - & $9 / 26(35 \%)^{\circ}$ & $\circ$ & $\begin{array}{c}3 / 3 \\
(100 \%)^{\circ 0}\end{array}$ & \\
\hline Karban et al. (43) & 200 & PB & $\begin{array}{l}200 / 20 \\
(100 \%)\end{array}$ & $\begin{array}{c}4 / 46 \\
(8,7 \%)\end{array}$ & - & - & - & - & - & - \\
\hline
\end{tabular}




\begin{tabular}{|c|c|c|c|c|c|c|c|c|c|c|}
\hline Reference & $\begin{array}{l}\text { No. } \\
\text { Patients }\end{array}$ & Samples evaluated & CLL & MCL & $\mathrm{HCL}$ & HCL-v & MZL & FL & LPL & Other B-cell neoplasms \\
\hline Sorigue et al. (44) & 248 & PB; BM; LN; CE & 106/106 (100\%) & - & - & - & - & - & - & $\begin{array}{l}\text { MBL-CLL like: } 106 / 106 \text { (100\%); DLBCL: 7/ } \\
32 \text { (22\%) of which 4/11 (36\%) ABC; 3/20 } \\
\text { (15\%) GCB; 0/1 (0\%) cell of origin not } \\
\text { determined; } 1 / 4 \text { (25\%) BL. }\end{array}$ \\
\hline Lesesve et al. (45) & 124 & PB; BM & $\begin{array}{l}57 / 69 \\
(83 \%)\end{array}$ & $\begin{array}{l}0 / 10 \\
(0 \%)\end{array}$ & $2 / 4(50 \%)$ & - & $\begin{array}{l}1 / 16 \\
(6 \%)\end{array}$ & $\begin{array}{l}0 / 7 \\
(0 \%)\end{array}$ & - & $\begin{array}{l}\text { MBL-CLL like: 8(13(61\%); MBL-non-CLL } \\
\text { like 1/3(33\%); } \\
\text { PL: 0/2 (0\%) }\end{array}$ \\
\hline Fan et al. (46) & 374 & PB; BM & $\begin{array}{c}268 / 271 \\
(99 \%)\end{array}$ & $1 / 31(35 \%)$ & $3 / 3(100 \%)$ & - & $75 \%$ strong & - & - & PL: 5/7 (\%) weakly, 2/7 (\%) strong \\
\hline Naseem et al. (47) & 77 & Not reported & $54 / 54(100 \%)$ & $1 / 6(16 \%)$ & $5 / 5(100 \%)$ & - & - & $1 / 2(50 \%)$ & - & Other CLPD did not express CD200 \\
\hline Rahman et al. (48) & 3 & Not reported & - & - & - & $3 / 3(100 \%)$ & - & - & - & - \\
\hline Rahman et al. (49) & 160 & $\begin{array}{l}\text { PB; BM; FNA, } \\
\text { ascites fluid }\end{array}$ & 98/98 (100\%) & 0/24 (0\%) & 6/6 (100\%) & $0 / 1(0 \%)$ & $3 / 6(50 \%)$ & $2 / 4(50 \%)$ & $\begin{array}{c}2 / 4 \\
(50 \%)\end{array}$ & $\begin{array}{l}\text { DLBCL: } 3 / 5 \text { (60\%); BL: 0/1 (0\%); PBL: 0/1 } \\
\text { (0\%); CD5-CD10- undefined lymphomas: } \\
\text { 4/10 (40\%) }\end{array}$ \\
\hline Ting et al. (50) & 97 & $\begin{array}{l}\text { PB; BM; LN; pleural } \\
\text { fluid }\end{array}$ & $56 / 56(100 \%)^{\S}$ & 0/6 (0\%) & $2 / 2(100 \%)$ & - & - & - & - & $\begin{array}{l}40 \text { pts of which } 22 \text { diagnosed with } \\
\text { lymphomas with subtype (not reported in } \\
\text { the paper), and } 18 \text { unclassified (of which } \\
10 \text { diagnosed with lymphoma without } \\
\text { subtype, and } 8 \text { non-CLL MBL) }\end{array}$ \\
\hline Arlindo et al. (51) & 124 & PB; BM & $\begin{array}{c}61.1 \\
(41.4 / 89.2)\end{array}$ & $\begin{array}{c}3.5 \\
(2.1 / 4.1)\end{array}$ & $\begin{array}{c}220.3 \\
(163.1 / 297.5)\end{array}$ & $\begin{array}{c}36.1 \\
(22.1 / 50.1)\end{array}$ & $\begin{array}{c}8.3 \\
(4.5 / 13.2)\end{array}$ & $\begin{array}{c}2.6 \\
(1.8 / 11.4)\end{array}$ & & Atypical CLL: 113.7 (70.4/122.2) \\
\hline Mason et al. (52) & 79 & $\mathrm{~PB} ; \mathrm{BM} ; \mathrm{LN}$ & - & - & $\begin{array}{c}34 / 34 \\
(100 \%)\end{array}$ & $\begin{array}{l}0 / 3 \\
(0 \%)\end{array}$ & $\begin{array}{l}1 / 22 \\
(5 \%)\end{array}$ & - & $\begin{array}{l}13 / 20 \\
(65 \%)\end{array}$ & \\
\hline Starostka et al. (53) & 188 & $\begin{array}{l}\text { PB; BM; LN; pleural } \\
\text { fluid }\end{array}$ & $\begin{array}{l}158 / 161 \\
(98.3 \%)\end{array}$ & $7.9 \%$ & - & - & $63.6 \%$ & - & - & \\
\hline Miao et al. (54) & 653 & PB; BM & 355/365 (97\%) & $12 / 41(29 \%)$ & $1 / 1(100 \%)$ & 2/2 (66.7\%) & 8/20 (40\%) & $\begin{array}{c}13 / 17 \\
(76.5 \%)\end{array}$ & $\begin{array}{l}30 / 35 \\
(85.7 \%)\end{array}$ & $\begin{array}{l}\text { MALToma: 4/4 (100\%); CD5+ and CD5- } \\
\text { unclassified B-cell chronic } \\
\text { lymphoproliferative disorders: 119/153 } \\
(78 \%)\end{array}$ \\
\hline Poongodi et al. (55) & 77 & PB; BM & $\begin{array}{l}54 / 54 \\
(100 \%)\end{array}$ & $1 / 6(16,7 \%)$ & $5 / 5(100 \%)$ & - & 2/2 (100\%) & $1 / 2(50 \%)$ & - & $\begin{array}{l}\text { DLBCL: 1/3 (33.3\%); unclassifiable } \\
\text { lymphoma: 2/3 (66.7\%); SLL: 1/1 (100\%) }\end{array}$ \\
\hline Favre et al. (56) & 96 & PB & $84 / 84(100 \%)$ & $1 / 30(3 \%)$ & $7 / 7$ (100\%) & - & 13/14 (93\%) & - & - & SRPBL: 6/15 (40\%) \\
\hline Falay et al. (57) & 339 & PB; BM & $\begin{array}{c}295 / 306^{9} \\
(95.8 \%)\end{array}$ & $\begin{array}{c}2 / 33 \\
(6.1 \% \text { dimly) }\end{array}$ & - & - & - & - & - & \\
\hline D'Arena et al. (58) & 427 & PB; BM & $\begin{array}{c}312 / 322 \\
(97 \%)\end{array}$ & $\begin{array}{l}4 / 21 \\
(19 \%)\end{array}$ & $15 / 15(100 \%)$ & - & $27 / 53(51 \%)$ & $3 / 12(25 \%)$ & $\begin{array}{l}0 / 4 \\
(0 \%)\end{array}$ & \\
\hline Debord et al. (59) & 135 & PB, BM & - & 3/63 (5\%) & - & - & - & - & - & $\begin{array}{l}\text { 68/72 (94\%) low grade B-cell lymphoma } \\
\text { not otherwise specified }\end{array}$ \\
\hline Mora et al. (60) & 120 & PB & $\begin{array}{l}64 / 64 \\
(100 \%)\end{array}$ & $\begin{array}{l}1 / 5 \\
(20 \%)\end{array}$ & - & - & $\begin{array}{l}13 / 19 \\
(68.4 \%)\end{array}$ & $\begin{array}{c}2 / 2 \\
(100 \%)\end{array}$ & - & $\begin{array}{l}\text { MBL: } 14 / 14 \text { (100\%); SLL: 3/3 (100\%); } \\
\text { other B-CLPD (not otherwise specified): 9/ } \\
13(69.2 \%)^{\wedge}\end{array}$ \\
\hline Myles et al. (61) & 307 & $\begin{array}{l}\text { PB; BM; LNH, other } \\
\text { body fluid or tissue }\end{array}$ & 231/241 (96\%) & 62/66 (94\%) & - & - & - & - & - & \\
\hline
\end{tabular}




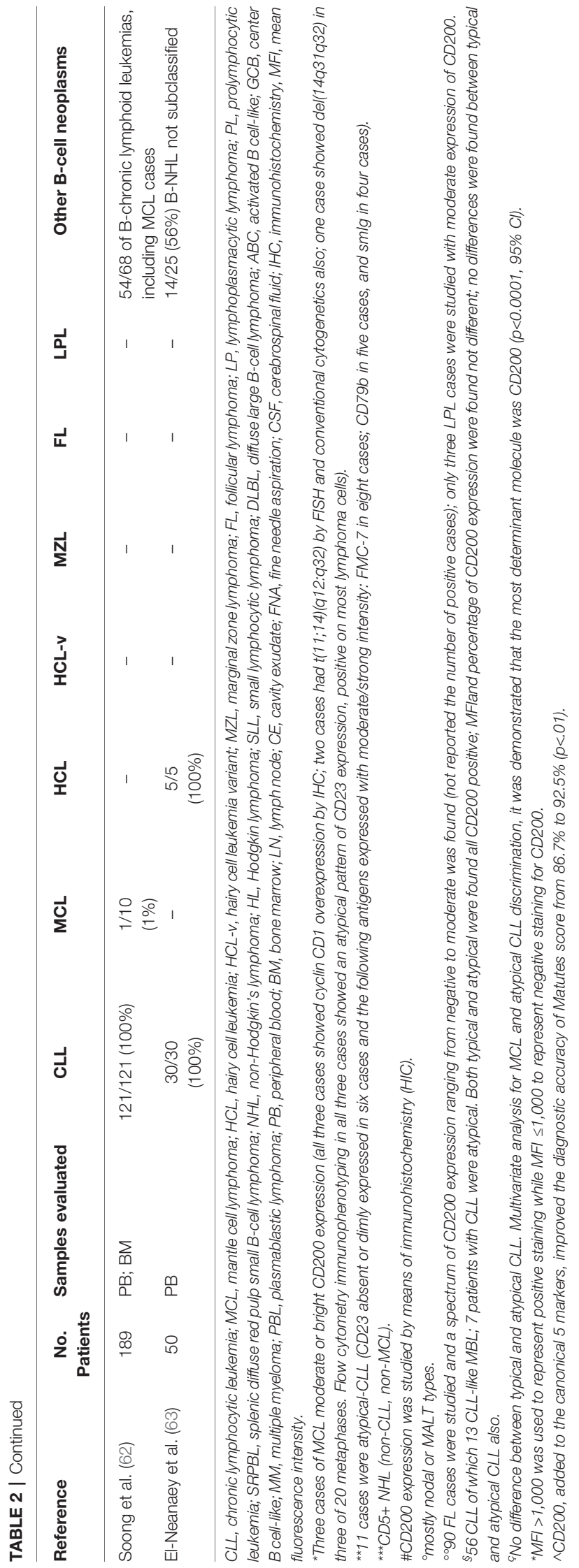

CLL and HCL and the negativity in almost all patients with MCL (Table 2).

Focusing on the assessment of fluorescence intensity of CD200, Lesesve et al used the ratio of mean fluorescence intensity (MFI) of CD160/CD200 on leukemic cells/controls (45). CD160 is a glycosylphosphatidylinositol-anchored cell surface molecule belonging to the immunoglobulin superfamily that was found to be expressed in patients with CLL $(64,65)$. Only $60 \%$ of patients showed surface positivity for CD160. Both markers were positive in $55 \%$ of CLL but only in $2 \%$ of other Bcell neoplasms, and absence of both markers occurred in $12 \%$ of CLL and in $86 \%$ of other B-cell neoplasms.

Taken together, these data showed that CD200 has a high sensitivity for CLL diagnosis, being expressed in most of the CLL cases. However, it is expressed also in other B-cell malignancies, including MZL, HCL, and even some cases with indolent, nonnodal entity MCL, thus showing low specificity.

Some authors tried to implement the diagnostic ability of monoclonal antibodies-based scores using CD200 (58, 66-68). Recently, Köhnke et al proposed the so-called "CLLflow score" including CD200 in the Matutes score and showing an improvement in the specificity for the diagnosis of CLL (66). Briefly, the score is calculated by adding the percentage of $\mathrm{CD} 200+$ and $\mathrm{CD} 23+/ \mathrm{CD} 5+\mathrm{B}$ cells and then subtracting the percentages of CD79b+ as well as FMC7+ B cells. A score $>0$ is consistent with the diagnosis of CLL while a score $\leq 0$ with the diagnosis of a non-CLL disease entity (67-69). In our hands a simplified score system for the diagnosis of CLL, in which only 4 markers are used (CD5, CD23, CD200, and SmIg), showed a higher sensitivity and specificity with respect to the Matutes score (58).

Interestingly, very recently Sorigue et al, using three immunophenotype-based diagnostic approaches (Matutes score, D'Arena score and CD43 expression) analyzed 597 patients with a chronic lymphoproliferative disorder (CLPD) and found that patients with concurring CLL-like or non-CLL like results according to the three diagnostic strategies were diagnosed with CLL $(\mathrm{n}=441)$ and non-CLL $(\mathrm{n}=99)$, respectively (Figure 3) $(69,70)$. 'Discordant' patients $(n=57)$ were further re-evaluated taking into account individual cytometric markers and cytogenetics data and only 16 patients (2.7\%) were not assigned to a reasonable diagnosis (Figure 3 ). The latter cases were considered "borderline lymphoproliferative disorders", a loosely-defined concept that would include any chronic lymphoid disorder in which the diagnosis of CLL cannot be either made or ruled out.

In another recent study, Sorigue et al conducted a systematic review of the use of CD200 in the differential diagnosis of CLPDs (71). They evaluated the positive predictive value of CD200 on the prevalence of the disorders evaluated for the differential diagnosis. Twenty-seven publications were included in this systematic review (accounting for 5,764 patients). The median positivity rate and percentage of CD200 positive cells in patients with CLL was $100 \%$ and $95 \%$, respectively, whereas it was $4 \%$ and $8 \%$ in MCL, and $56 \%$ and $62 \%$ in other CLPDs. The authors concluded that CD200 is a suboptimal marker in discriminating 


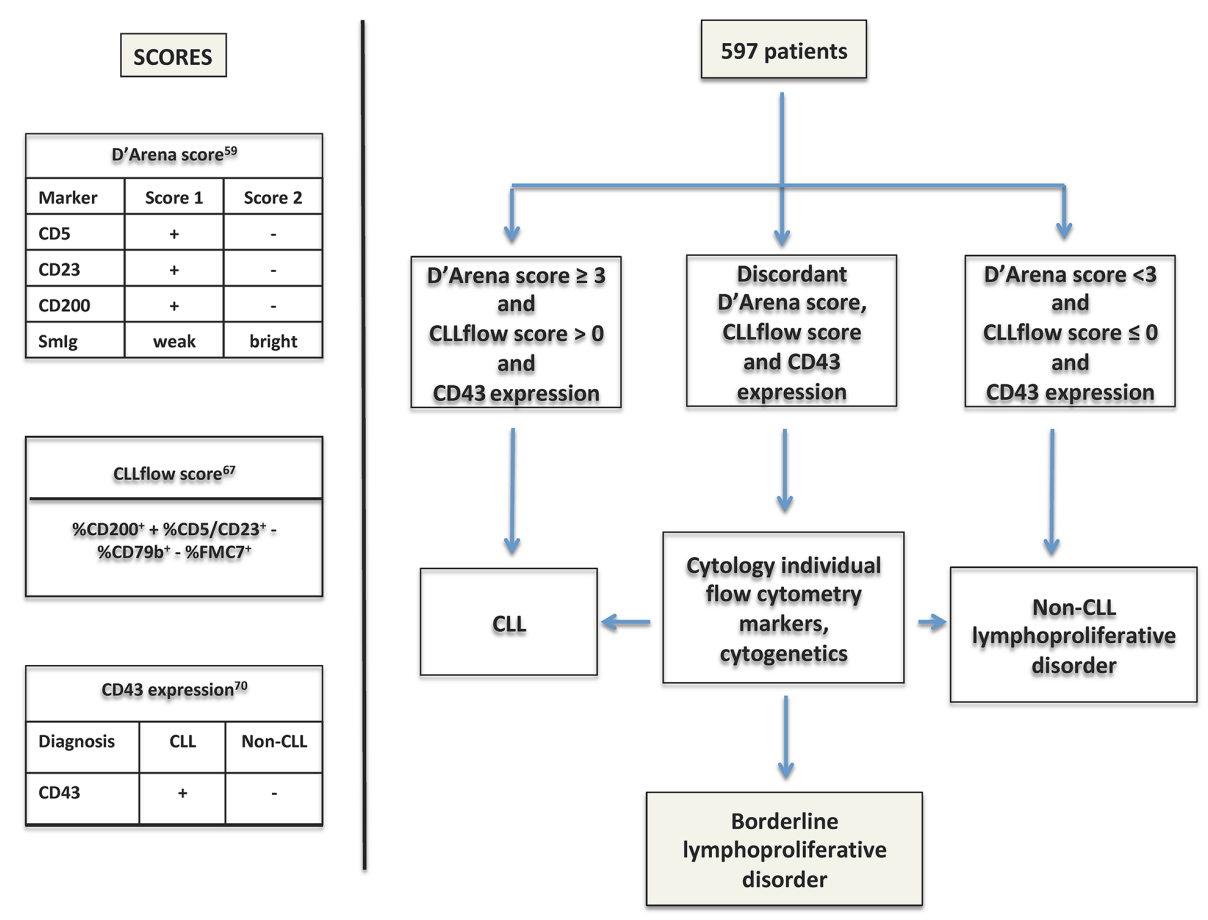

FIGURE 3 | Overview of the study by Sorigue et al. (70). The algorithm of the study using the three diagnostic scores to assign a diagnostic category is explained in the text $(58,66,69)$.

CLL from CLPDs other than MCL. These findings suggest that assessment of CD200 within scores rather than as a single marker, as reported by some authors, would be more useful (66-68).

In addition, some authors investigated whether a different expression of CD200 between CLL and monoclonal B-cell lymphocytosis (MBL) exists. Sorigue et al demonstrated that all cases of both CLL and CLL-like MBL were CD200 positive. However, MBL cases showed a lower CD200 MFI than CLL. Moreover, both CLL with trisomy 12 and CLL-like MBL displayed lower CD200 MFI than CLL with other cytogenetic abnormalities. In contrast, Rawstron et al did not find any difference in expression of a large body of markers, including CD200, between CLL-type MBL and CLL (72). However, differences in the expression of other markers were observed, including lower expression of CD38, CD62L, and CD49d and higher expression of LAIR-1, CXCR5, and CCR6 on CLL-type MBL compared to CLL. In conclusion, despite CLL-type MBL being phenotypically identical to CLL for a large body of antigens, certain differences exist, particularly with respect to proteins involved in the homing to lymphoid tissue.

\section{CD200 AND PROGNOSIS IN CLL}

Little is known about the prognostic significance of CD200 expression in CLL. As a matter of fact, conflicting results have been reported so far. Few data have been published and both percentage of CD200 positivity and fluorescence intensity have been used to estimate CD200 expression on CLL Blymphocytes. Firstly, Wang et al in 2014 identified two distinct groups of CLL patients according to the expression of CD200 on bone marrow B cells (CD200 low group: $<50 \%$; CD200 high group: $\geq 50 \%$ ) (73). As reported in Table 3, correlations were found with some clinical-biological features of CLL patients with $<50 \% \mathrm{CD} 200+$ cells. In contrast, using the same methodological approach, El Din Fouad et al found other correlations in patients with a lower percentage of CD200+ CLL cells $(<50 \%)(74)$. Moreover, while the former study did not report data on TTT, response to therapy or OS, the latter found no correlation with response to treatment or OS. In a large cohort of patients with CLL, Miao et al, evaluating the CD200 mean fluorescence intensity (MFI) instead of the percentage of positivity, found that patients with lower CD200 MFI had a significantly shorter TTT with respect to patients with higher CD200 MFI (75). However, no correlation was found between CD200 MFI and OS, and CD200 MFI did not maintain its predictive value on TTT in multivariate analysis. More recently, using a more standardized flow cytometric approach, we measured the CD200 MFI on CD19+ and CD19- lymphocyte subpopulations, calculating the relative fluorescence intensity (RFI) as a ratio of the CD200 MFI on CD19+ and CD19- cells (76). Lower and higher CD200 RFI values were found to be associated with del11q and del13q14, respectively. In addition, 
TABLE 3 | CD200 expression and prognosis in CLL.

\begin{tabular}{|c|c|c|c|}
\hline Reference & $\begin{array}{l}\text { No. } \\
\text { Patients } \\
\text { evaluated }\end{array}$ & CD200 positivity cut-off & Correlations \\
\hline Wang et al. (73) & 40 & $\begin{array}{l}50 \% \text { of B-cells } \\
\text { (<50\%: CD200 low group; } \\
\geq 50 \% \text { CD200 high group) }\end{array}$ & $\begin{array}{l}<50 \% \text { of CD200-positive B-cells positively correlated with younger age, female gender, lower WBC, } \\
\text { lower lymphocyte absolute and percentage number, lower lymph node involvement, lower ZAP-70 } \\
\text { positive cells, early disease stage. No data on TT, response to therapy and OS. }\end{array}$ \\
\hline $\begin{array}{l}\text { El Din Fouad et al. } \\
(74)\end{array}$ & 43 & $50 \%$ of B-cells & $\begin{array}{l}>50 \% \text { of CD200-positive B-cells positively correlated with older age, lymphocytosis, hepatomegaly, } \\
\text { splenomegaly, higher Rai and Binet stage. No correlation with response to treatment and OS. }\end{array}$ \\
\hline Miao et al. (75) & 307 & $\begin{array}{l}\text { CD200 MFI } \\
\text { cut-off: } 189.5 \\
\text { (<lower group; } \\
\text { zhigher group) }\end{array}$ & Lower CD200 MFI positively correlated with shorter TT. \\
\hline D’Arena et al. (76) & 105 & $\begin{array}{l}\text { CD200 RFI } \\
\text { cut-off: } 13\end{array}$ & $\begin{array}{l}\text { Lower CD200 RFI positively correlated with del11q and negatively correlated with del13q14. } \\
\text { CD200 RFI greater than the mean value of the entire cohort positively correlated with longer OS. }\end{array}$ \\
\hline
\end{tabular}

WBC, white blood cell count; TIT, time to treatment; OS, overall survival; MFI, mean fluorescence intensity; RFI, relative fluorescence intensity (ratio of MFI of CD200 on CD19+ lymphocytes/MFI of CD200 on CD19- lymphocytes).

CD200 RFI greater than the mean cohort value was detected in patients with longer OS. However, these data have to be confirmed in patients with a longer follow-up.

In summary, conflicting results have been reported on the prognostic role of CD200 expression in CLL so far. Methodological and sampling differences, such as the analysis of percentage of positive cells versus MFI, bone marrow versus peripheral blood cells, and different flow cytometry instrument settings and/or gating strategy, could account for these differences. Further studies are needed to better understand this issue before reaching definitive conclusions.

\section{CONCLUSIONS AND FUTURE DIRECTIONS}

CD200 expression is useful in better classifying B-cell CLPDs. The addition of CD200 to flow cytometry marker panels addressing the diagnosis of this heterogenous group of $\mathrm{B}$ cell neoplasms may be particularly helpful in distinguishing some disease entities, in particular CLL and MCL, whose clinical behavior and prognosis are quite different. On the contrary, expression of CD200 does not appear to have a relevant role as a prognostic indicator in CLL according to data published so far, despite limited in number. However, this issue needs to be better addressed by studies on a larger cohort of patients and using standardized methodologies. Finally, the potential role of CD200 as a therapeutic target must be taken into account in particular for diseases that highly express CD200, such as CLL and HCL $(24,77)$. In fact, CD200 is known to act as an immunosuppressive molecule that is upregulated on primary CLL B-cells (18). Moreover, an elegant work by Kretz-Rommel and co-workers demonstrated that CD200 expression by tumor cells suppresses antitumor responses in an animal model (22). In a similar fashion, Gorczynski et al showed that by manipulating CD200:CD200R interactions it is possible to cure local tumors and distant metastases in a murine breast cancer model $(78,79)$.
Very recently, the first-in-human study investigating the therapeutic use of the recombinant humanized monoclonal anti-CD200 antibody samalizumab in 23 patients with advanced CLL and 3 patients with MM was published (phase 1 study NCT00648738) (80). Treatment was associated with mild to moderate adverse events and resulted in a dose-dependent decrease in CD200 expression on CLL cells. Decreased tumor burden was also observed in 14 CLL patients, with one of them achieving a durable partial response, while 16 patients maintained a stable disease. These results, although preliminary, suggest that samalizumab could represent an immune checkpoint inhibitor with activity in CLL.

Finally, there is some evidence that serum levels of soluble CD200 may be related to disease progression and prognosis in patients with CLL $(79,81,82)$. In particular, Wong et al showed that CD200 can be released from CD200+ neoplastic cells by ectodomain shedding (81). This event is regulated by ADAM28 $(79,82)$. Interestingly, both the membrane and the soluble form of CD200 is able to engage CD200R, which in turn can result in increased tumor growth $(20,83)$. This happens by means of reduction of immune reactivity and/or increment of induction/ activation of regulatory $\mathrm{T}$ cells in the tumor microenvironment $(83,84)$. Taken together, more and more convincing data have been reported in the literature from which the relevant role of CD200 is emerging not only as a diagnostic and prognostic tool but also as a potential therapeutic target in various neoplasms including CLL.

\section{AUTHOR CONTRIBUTIONS}

GD'A, GP, VD, FA, SD, DE, AS, and LL designed the project, revised the scientific literature, and wrote the paper. GD'A, GP, ES, GM, and OV followed patients with chronic lymphocytic leukemia. FL, FD'A, TS, and LV performed flow cytometric studies. All authors contributed to the article and approved the submitted version. 


\section{REFERENCES}

1. McCaughan GW, Clark MJ, Hurst J, Grosveld F, Barclay AN. The gene for MRC OX-2 membrane glycoprotein is localised on human chromosome 3. Immunogenetics (1987) 25:133-5. doi: 10.1007/BF00364281

2. Mathews L, Farrar W. CD200 (CD200 molecule). Atlas Genet. Cytogenet. Oncol Hematol (2009) 13:793-8.

3. Barclay AN, Clark MJ, McCaughan GW. Neuronal/lymphoid membrane glycoprotein MRC OX-2 is a member of the immunoglobulin superfamily with a light-chain-like structure. Biochem Soc Symp (1986) 51:149-57.

4. Douglas J, Albertson DG, Barclay AN, Davis M, Rabbits PH. 2RFLP and mapping of human MOX-1 gene on chromosome 3. Nucleic Acids Res (1988) 16:9067. doi: $10.1093 /$ nar/16.18.9067

5. Wright GJ, Puklavec MJ, Willis AC, Hock RM, Sedgwick JD, Brown MH, et al. Lymphoid/neuronal cell surface OX2 glycoprotein recognizes a novel receptor on macrophages implicated in the control of their function. Immunity (2000) 13:233-42. doi: 10.4049/jimmunol.171.6.3034

6. Wright GJ, Jones M, Puklavec MJ, Brown JH, Barclay AN. The unusual distribution of the neuronal/lymphoid cell surface C200 (OX2) glycoprotein is conserved in humans. Immunology (2001) 102:173-9. doi: 10.1046/j13652567.2001.01163.x

7. Wright GJ, Cherwinski H, Foster-Cuevas M, Brooke G, Puklavec MJ, Bigler $\mathrm{M}$, et al. Characterization of the CD200 receptor family in mice and humans and their interactions with CD200. J Immunol (2003) 171:3024-46. doi: 10.4049/jimmunol.171.6.3034

8. Kawasaki BT, Farrar WL. Cancer stem Cells, CD200 and immunoevasion. Trends Immunol (2008) 29:464-8. doi: 10.1016/j.it.2008.07.005

9. Gorczynski R, Khatri I, Lee L, Boudakov I. An interaction between CD200 and monoclonal antibody agonists to CD200R2 in development of dendritic cells that preferentially induce populations of $\mathrm{CD} 4+\mathrm{CD} 25+\mathrm{T}$ regulatory cells. J Immunol (2008) 180:5946-55. doi: 10.4049/jimmunol.180.9.5946

10. Gorczynski RM, Lee L, Boudakov I. Augmented induction of CD4+CD25+ Treg using monoclonal antibodies to CD200R. Transplantation (2005) 79:488-91.

11. Zhang S, Cherwinski H, Sedgwick JD, Phillips JH. Molecular mechanisms of CD200 inhibition of mast cell activation. J Immunol (2004) 173:6786-93. doi: 10.4049/jimmunol.173.11.6786

12. Cherwinski HM, Murphy CA, Joyce BL, Bigler ME, Song YS, Zurawski SM, et al. The CD200 receptor is a novel and potent regulator of murine and human mast cell function. J Immunol (2005) 174:1348-56. doi: 10.4049/ jimmunol.174.3.1348

13. Shiratori I, Yamaguchi M, Suzukawa M, Yamamoto K, Lanier LL, Saito T, et al. Down-regulation of basophil function by human CD200 and human herpesvirus-8 CD200. J Immunol (2005) 175:4441-9. doi: 10.4049/ jimmunol.175.7.4441

14. Coles SJ, Wang ECY, Man S, Hills RK, Burnett AK, Tonks A, et al. CD200 expression suppresses natural killer cell function and directly inhibits patient anti-tumor response in acute myeloid leukemia. Leukemia (2011) 25:792-9. doi: 10.1038/leu.2011.1

15. Hoek RM, Ruuls SR, Murphy CA, Wright GJ, Goddard R, Zurawski SM, et al. Down-regulation of the macrophage lineage through interaction with OX2 (CD200). Science (2000) 290:1768-71. doi: 10.1126/science.290. 5497.1768

16. Gorczynski L, Chen Z, Hu J, Kai Y, Lei V, Ramakrishna V, et al. Evidence that an OX2-positive cell can inhibit the stimulation of typel cytokine production by bone marrow-derived B7-1 (and B7-2)-positive dendritic cells. J Immunol (1999) 162:774-81.

17. Gorczynski RM. Transplant tolerance modifying antibody to CD200 receptor, but not CD200, alters cytokine production profile from stimulated macrophages. Eur J Immunol (2001) 31:2331-7. doi: 10.1002/1521-4141 (200108)31:8<2331::aid-immu2331>3.0.c0:2-\#

18. McWhirter JRA, Kretz-Rommel A, Saven T, Maruyama T, Potter KN, Mockridge CI, et al. Antibodies selected from combinatorial libraries block a tumor antigen that plays a key role in immunomodulation. Proc Natl Acad Sci USA (2006) 103:1041-6. doi: 10.1073/pnas.0510081103

19. Moreaux J, Veyrune JL, Reme T, De Vos J, Klein B. CD200: a putative theraputic target in cancer. Biochem Biophys Res Commun (2008) 366:117-22. doi: $10.1016 /$ j.bbrc.2007.11.103
20. Moreaux J, Hose D, Reme T, Jourdan E, Hundemer M, Legouffe E, et al. CD200 is a new prognostic factor in multiple myeloma. Blood (2006) 108:4194-7. doi: 10.118/blood-2006-06-029355

21. Tonks A, Hills R, White P, Rosie B, Mills KI, Burnett AK, et al. CD200 as a prognostic factor in acute myeloid leukaemia. Leukemia (2007) 21:566-8. doi: 10.1038/sj.leu.2404559

22. Kretz-Rommel AF, Qin N, Dakappagari EP, Ravey EP, McWhirter J, Oltean D, et al. CD200 expression on tumor cells suppresses antitumor immunity: new approaches to cancer immunotherapy. J Immunol (2007) 178:5595-602. doi: 10.4049/jimmunol.178.9.5595

23. Kretz-Rommel A, Bowdish KS. Rationale for anti-CD200 immunotherapy in B-CLL and other hematologic malignancies: new concepts in blocking immune suppression. Expert Opin Biol Ther (2008) 8:5-15. doi: 10.1517/ 14712598.8.1.5

24. Kretz-Rommel A, Qin F, Dakappagari N, Cofiell R, Faas SJ, Bowdish KS. Blockade of CD200 in the presence or absence of antibody effector function: implications for anti-CD200 therapy. I Immunol (2008) 180:699-705. doi: 10.4049/jimmunol.180.2.699

25. Swerdlow SH, Campo E, Harris NL, Jaffe ES, Pileri SA, Stein H, et al. WHO classification of tumours of haematopoietic and lymphoid tissues. In: FT Bosman, ES Jaffe, SR Lakhani, H Ohgaki, editors. World Health Organization Classification of Tumours. Lyon, France: IARC (2008).

26. Swerdlow SH, Campo E, Pileri SA, Harris NL, Stein H, Siebert R, et al. The 2016 revision of the World Health Organization classification of lymphoid neoplasms. Blood (2016) 127:2375-90. doi: 10.1182/blood-2016-01-643569

27. D'Arena G, Keating MJ, Carotenuto M. Chronic lymphoproliferative disorders: an integrated point of view for the differential diagnosis. Leuk Lymphoma (2000) 36(3-4):225-37. doi: 10.3109/1042819000914884 2000.

28. Matutes E, Owusu-Ankomah K, Morilla R, Garcia Marco J, Houlihan A, Que $\mathrm{TH}$, et al. The immunological profile of B-cell disorders and proposal of a scoring system for the diagnosis of CLL. Leukemia (1994) 8:1640-5.

29. Moreau E, Matutes E, A'Hern RP, Morilla AM, Owusu-Ankomah A, Seon BK, et al. Improvement of the chronic lymphocytic leukemia scoring system with the monoclonal antibody SN8 (CD79b). Am J Clin Pathol (1997) 108:378-82. doi: $10.1093 / \mathrm{ajcp} / 108.4 .378$

30. Brunetti L, Di Noto R, Abate G, Gorrese A, Gravetti A, Raia M, et al. CD200/ OX2, a cell surface molecule with immuno-regulatory function is consistently expressed on hairy cell leukaemia neoplastic cells. Br J Haematol (2009) 145:665-7. doi: 10.1111/j.1365-2141.2009.07644.x

31. Palumbo GA, Parrinello N, Fargione G, Cardillo K, Chiarenza A, Berretta S, et al. CD200 expression may help in differential diagnosis between mantle cell lymphoma and B-cell chronic lymphocytic leukemia. Leuk Res (2009) 33:1212-6. doi: 10.1016/j.leukeres.2009.01.017

32. Dorfman DM, Shahsafaei A. CD200 (OX-2 membrane glycoprotein) expression in B cell-derived neoplasms. Am J Clin Pathol (2010) 134:72633. doi: 10.1309/AJCP38XRRUGSQOVc

33. Bhatnagar N, Wright F, McAleese D, McNamara CJ. The utility of CD200 expression in the differentiation on mantle cell lymphoma and B-cell chronic lymphocytic leukemia: a single centre experience. Blood (2010) 116(21):702. doi: 10.1182/blood.V116.21.1673.1673

34. El Desoukey NA, Afify RA, Amin DG, Mohammed RF. CD200 expression in B-cell chronic lymphoproliferatve disorders. J Invest Med (2012) 60:56-61. doi: 10.2310/JIM.0b13e31823908fb

35. Cherian S, Bohling S, Wilson M, Levin G, Wood B. Utility of CD200 in the diagnosis of chronic lymphocytic leukemia. Cytometry Part B- Clin Cytom (2012) 82B(5):329.

36. Kern W, Schabath R, Haferlach C, Schnittger S, Haferlach T. Diagnostic value of CD200 expression for the differentiation between chronic lymphocytic leukemia (CLL), CLL with increased prolymphocytes (CLL/PL) and mantle cell lymphoma. Blood (2012) 120(21):2660. doi: 10.1182/blood.V120.21. 2660.2660

37. Alapat D, Coviello-Maile JM, Owens R, Qu P, Barlogie B, Shaughnessy JD, et al. Diagnostic usefulness and prognostic impact of CD200 expression in lymphoid malignancies and plasma cell myeloma. Am J Clin Pathol (2012) 137:93-100. doi: 10.1309/AJCP59UORCYZEVQO

38. Pillai V, Pozdnyakova O, Charest K, Li B, Shahsafaei A, Dorfman DM. CD200 flow cytometric assessment and semiquantitative immunohistochemical staining distinguishes hairy cell leukemia from hairy cell leukemia-variant 
and other B-cell lymphoproliferative disorders. Am J Clin Pathol (2013) 140:536-43. doi: 10.1309/AJCPEBK31VQQNDDR

39. Dasgupta A, Ramani M, Mehrotra V, Parab S, Yadav J, Gujarathi P. CD200 expression in B-chronic lymphocytic leukemia - it is not an all or none phenomenon. Cytometry Part B- Clin Cytom (2013) 84(6):406.

40. El-Sewefy DA, Khattab DA, Sallam MTH, Elsalakawy WA. Flow cytometric evaluation of $\mathrm{CD} 200$ as a tool for differentiation between chronic lymphocytic leukemia and mantle cell lymphoma. Egyptian J Haematol (2014) 39:42-6.

41. Sandes AF, Chauffaille ML, Oliveira CRMC, Maekawa Y, Tamashiro N, Takao TT, et al. CD200 has an important role in the differential diagnosis of mature B-cell neoplasms by multioparameter flow cytometry. Cytometry B Clin Citom (2014) 86:98-105. doi: 10.1002/cyto.b.21128

42. Challagundla P, Medeiros LJ, Kanagal-Shamanna R, Miranda RN, Jorgensen JL. Differential expression of CD200 in B-cell neoplasms by flow cytometry can assist in diagnosis, subclassification, and bone marrow staging. Amer J Clin Pathol (2014) 142:837-44. doi: 10.1309/AJCPBV9ELXCOECVL

43. Karban J, Radek M, Babunkova E, Kvasnicka J, Jaksa R, Berkova A, et al. CD200 expression improves differential diagnosis between chronic lymphocytic leukemia and mantle cell lymphoma. Blood (2014) 124 (21):5637. doi: 10.1182/blood.V124.21.5637.5637

44. Sorigue M, Junca J, Grananda I. CD200 in high-grade lymphoma, chronic lymphocytic leukemia, and chronic lymphocytic leukemia-phenotype monoclonal B-cell lymphocytosis. Am J Clin Pathol (2015) 144:676-9. doi: 10.1309/AJCP02KKFMOEXNZF

45. Lesesve J-F, Tardy S, Frotscher B, Latger-Cannard V, Feugier P, De Carvalho M, et al. Combination of CD160 and CD200 as a useful tool for differential diagnosis between chronic lymphocytic leukemia and other mature B-cell neoplasms. Int J Lab Hematol (2015) 37:486-94. doi: $10.1111 / \mathrm{ijlh} .12315$

46. Fan L, Miao Y, Yu-Jie W, Wang J, Guo R, Wang L, et al. Expression patterns of CD200 and CD148 in leukemic B-cell chronic lymphoprolifeartive disorders and their potential value in differential diagnosis. Leuk Lymphoma (2015) 56:3329-35. doi: 10.3109/10428194.2015.1030642

47. Naseem S, Poongodi R, Varma N, Malhotra P, Varma S. Utility of CD200 expression and CD20 antibody binding capacity in differentiating chronic lymphocytic leukemia from other chronic lymphoproliferative disorders. Blood (2015) 126(23):5278. doi: 10.1182/blood.V126.23.5278.5278

48. Rahman K, Kumari S, Singh MK, Gupta R, Yadov G, Kumari N, et al. Atypical presentation of hairy cell leukemia: significance of CD200 on flow cytometry. J Canc Res Ther (2018) 14:1130-4. doi: 10.4103/0974-1482.188432

49. Rahman K, Kumar K, Gupta R, Singh MK, Nityanand S. Role of CD200 in differential diagnosis of mature B-cell neoplasms. Int J Lab Hematol (2017) 39:384-91. doi: 10.111/ijlh.12637

50. Ting YS, Smith SABC, Brown DA, Dodds AJ, Fay KC, Ma DDF, et al. CD200 is a useful diagnostic marker for identifying atypical chronic lymhocytic leukemia by flow cytometry. Int J Lab Hematol (2018) 40(5):533-9. doi: 10.1111/ijlh.12857 May 27.

51. Arlindo EM, Marcondes NA, Fernandes FB, Faulhaber GAM. Quantitative flow cytometric evaluation of CD200, CD123, CD43 and CD52 as a tool for the differential diagnosis of mature B-cell neoplasms. Rev Bras Hematol Hemother (2017) 39:252-8. doi: 10.1016/j.bjhh-2017.05.002

52. Mason EF, Pzdnyakova O, Li B, Dudley G, Dorfman DM. Flow cytometric patterns of $\mathrm{CD} 200$ and $\mathrm{cD} 1 \mathrm{~d}$ expression distinguish CD10-negative, CD5negative mature B-cell lymphoproliferative disorders. Am J Clin Pathol (2017) 148:33-41. doi: 10.1093/AJCP/AQX041

53. Starostka D, Kriegova E, Kudelka M, Mikula P, Zehnalova S, Radvansky M, et al. Quantitative assessment of informative immunophenotypic markers increases the diagostic value of immunophenotyping in mature CD5-positive B-cell neoplasms. Cytometry Part B - Clin Cytometry (2017) 94B:576-87. doi: 10.1002/cyto.b.21607

54. Miao Y, Cao L, Sun Q, Li X-T, Wang Y, Qiao C, et al. Spectum and immunophenotyping of 653 patients with B-cell chronic lymphoproliferative disorders in China: a single-centre analysis. Hematol Oncol (2018) 36:121-7. doi: 10.1002/hon.2461

55. Poongodi R, Varma N, Naseem S, Parveen B, Varma S. Utility of CD200 expression and $\mathrm{CD} 20$ antibody binding capacity in differentiating chronic lymphocytic leukemia from other chronic lymphoproliferative disorders. Indian J Pathol Microb (2018) 61:50-7. doi: 10.4103/IJPM.IJPM_267_17
56. Favre R, Manzoni D, Traverse-Glehen A, Verney A, Jallades L, Callet-Bauchu E, et al. Usefulness of CD200 in the differential diagnosis of SDRPL, SMZL, and HCL. Int J Lab Hem (2018) 40:e59-62. doi: 10.1111/ijlh.12824

57. Falay M, Ozturk BA, Gunes K, Kalpakci Y, Dgdas S, Ceran F, et al. The role of CD200 and CD43 expression in differential diagnosis between chronic lymphocytic leukemia and mantle cell lymphoma. Turk J Hematol (2018) 35:94-8. doi: 10.4274/tih.2017.0085

58. D'Arena G, Vitale C, Rossi G, Coscia M, Omedè P, D'Auria F, et al. CD200 included in a 4-marker modified Matutes score provides optimal sensitivity and specificity for the diagnosis of chronic lymphocytic leukaemia. Hematol Oncol (2018) 36:543-6. doi: 10.1002/hon.2510

59. Debord C, Robillard N, Theisen O, Gastinne T, Godmer P, Graveleau J, et al. CD200 expression in flow cytometry helps to distinguish mantle cell lymphoma from other CD5-positive B-cell neoplasms. Hematol Oncol (2018) 36:307-609. doi: 10.1002/hon.2511

60. Mora A, Bosch R, Cuellar C, Vicente EP, Blanco R, Martino JM, et al. CD200 is a useful marker in the diagnosis of chronic lymphocytic leukemia. Cytometry B Clin Cytom (2019) 96:143-8. doi: 10.1002/ cyto.b.217222

61. Myles N, Giri P, Chim I, Kodituwakku A. The utility of CD200 expression and modified Matutes score in the diagnostic differentiation of mantle cell lymhoma and chronic lymphocytic leukemia using flow cytometry. Leuk Lymphoma Sep (2019) 27:1-3. doi: 10.1080/10428194.2019.1663420

62. Soong N, Das-Dupta E, Dearden A. Evaluation of the diagnostic usefulness of CD200 marker in chronic lymphocytic leukaemia and mature B-cell lymphoproliferative disorders. Br J Haematol 2019 (2019) 185(Suppl. 1):87.

63. El-Neanaey WA, Swelem RS, Ghallab OM, Abu-Shelou SM. Evaluation of CD160 and CD200 expression as differentiating markers between chronic lymphocytic leukemia and other mature B-cell neoplasms. Int $J$ Hematol Oncol Stem Cell Res (2020) 14:27-37.

64. Anumanthan A, Bensussan A, Boumsell L, Christ AD, Blumberg RS, Voss SD, et al. Cloning of BY55, a novel Ig superfamily member expressed on NK cells, CTL, and intestinal intraepithelial lymphocytes. J Immunol (1998) 161:2780-90.

65. Liu FT, Giustiniani J, Farren T, Tia L, Bensussan A, Gribben JG, et al. CD160 signaling mediates PI3K-dependent survival and growth signals in chronic lymphocytic leukemia. Blood (2010) 115:3079-88. doi: 10.1182/blood-2009-08239483

66. Khonke T, Wittmann VK, Bucklein VL, Lichtenegger F, Pasalic Z, Hiddemann W, et al. Diagnosis of CLL revisited: increased specificity by a modified five-marker scoring system including CD200. Br J Haematol (2017) 179:480-7. doi: 10.1111/bjh.14901

67. Sorigue M, Franch-Sarto M, Sarrate E, Juca J. Usefulness of the CLLflow score. Cytometry B Clin Cytom (2018) 94(6):950-2. doi: 10.1002/cyto.b.21623

68. D’Arena G, Vitale C, Coscia M, D'Auria F, Bellesi G, Topini G, et al. External validation of the accuracy of 'CLLflow score'. J Investig Med (2018) 66(e):e6. doi: 10.1136/jim-2018-000832

69. Sorigue M, Junca J, Sarrate E, Grau J. Expression of CD43 in chronic lymphoproliferative leukemias. Cytometry B Clin Cytom (2018) 94:136-42. doi: 10.1002/cyto.b.21509

70. Sorigue M, Raya M, Vergara S, Serrate E, Orna E, Junca J. Refining the limits of borderline lymphoproliferative disorders. Cytometry B Clin Cytom (2018) 96:351-8. doi: 10.1002/cyto.b.21760

71. Sorigue M, Magnano L, Miljkovic MD, Nieto-Moragas J, Santos-Gomez M, Villamor N, et al. Positive predictive value of CD200 positivity in the differential diagnosis of chronic lymphocytic leukemia. Cytometry (2019) 98 (5):441-8. doi: 10.1002/cyto.b.21849

72. Rawstron AC, Shingles J, de Tute R, Bennett F, Jack AS, Hillmenn P. Chronic lymphocytic leukemia (CLL) and CLL-type monoclonal B-cell lymphocytosis (MBL) show differential expression of molecules involved in lymphoid tissue homing. Cytometry B Clin Cytom (2010) 78B(Suppl 1):S42-6. doi: 10.1002/ cyto.b. 20534

73. Wang X, Zhang Z, Liu Y, Wang L, Yuan H, Xie P, et al. Expression of CD200 in the bone marrow of chronic lymphocytic leukemia patients and its correlations with clinical prognosis. Chin J Cell Mol Immunol (2014) 30:75-8.

74. El Din Fouad NB, Ibrahim NY, Abdel Aziz RS, Ibrahim SK. CD200 expression in diagnostic and prognostic assessment of mature B cell lymphoproliferative 
neoplasms. Asian Pac J Cancer Prev (2018) 19:3383-92. doi: 10.31557/ APJCP.2018.19.12.338

75. Miao Y, Fan L, Wu Y-J, Xia Y, Qiao C, Wang Y, et al. Low expression of CD200 predicts shorter time-to treatment in chronic lymphocytic leukemia. Oncotarget (2016) 7:13551-62. doi: 10.18632/oncotarget.6948

76. D’Arena G, Valvano L, Vitale C, Coscia M, Statuto T, Bellesi S, et al. CD200 and prognosis in chronic lymphocytic leukemia: conflicting results. Leuk Res (2019) 83:106169. doi: 10.1016/j.leukres.2019.106169

77. Ljungars A, Martensson L, Mattson J, Kovacek M, Sundberg A, Tornberg UC, et al. A platform for phenotypic discovery of therapeutic antibodies and targets applied on chronic lymphocytic leukemia. Precis Oncol (2018) 2:18. doi: 10.1038/s41698-018-0061-2

78. Gorczynski RM, Chen Z, Khatri I, Podnos A, Yu K. Cure of metastatic growth of EMT6 tumor cells in mice following manipulation of CD200:CD200R signaling. Breast Cancer Res Treat (2013) 142:271-82. doi: 10.1007/s10549013-2735-3

79. Wong KK, Zhu F, Khatri I, Huo Q, Spaner DE, Gorczynski RM. Characterization of CD200 ectodomain shedding. PloS One 2016; (2016) 11:e0152073. doi: 10.1371/journal.pone.0152073

80. Mahadevan D, Lanasa MC, Farber C, Pandey M, Whelden M, Faas SJ, et al. Phase I study of samalizumab in chronic lymphocytic leukemia and multiple myeloma: blockade of the immune checkpoint CD200. J ImmunoTher Canc 7 (2019) 227:1-13. doi: 10.1186/s40425-019-0710-1

81. Wong KK, Brenneman F, Chesney A, Spaner DE, Gorczynski RM. Soluble CD200 is critical to engraft chronic lymphocytic leukemia cells in immunocompromised mice. Cancer Res (2012) 72:4931-43. doi: 10.1158/ 0008-5472.CAN-12-1390

82. Twito T, Chen Z, Khatri I, Wong K, Spaner D, Gorczynski RM. Ectodomain shedding of CD200 from the B-CLL surface is regulated by ADAM28 expression. Leuk Res (2013) 37:816-21. doi: 10.1016/j.leukres.2013.04.014

83. Norde WJ, Hobo W, van der Voort R, Dolstra H. Coinhibitory molecules in hematologic malignancies: targets for therapeutic intervention. Blood (2012) 120:728-36. doi: 10.1182/blood-2012-02-412510

84. Jadidi-Niaragh F, Yousefi M, Memarian A, Hojjat-Farsangi M, Khoshnoodi J, Razavi SM, et al. Increased frequency of CD8+ and CD4+ regulatory T cells in chronic lymphocytic leukemia: association with disease progression. Cancer Invest (2013) 31:121-31. doi: 10.3109/07357907.2012.756110

Conflict of Interest: The authors declare that the research was conducted in the absence of any commercial or financial relationships that could be construed as a potential conflict of interest.

Copyright (๐ 2020 D’Arena, De Feo, Pietrantuono, Seneca, Mansueto, Villani, La Rocca, D'Auria, Statuto, Valvano, Arruga, Deaglio, Efremov, Sgambato and Laurenti. This is an open-access article distributed under the terms of the Creative Commons Attribution License (CC BY). The use, distribution or reproduction in other forums is permitted, provided the original author(s) and the copyright owner(s) are credited and that the original publication in this journal is cited, in accordance with accepted academic practice. No use, distribution or reproduction is permitted which does not comply with these terms. 